\title{
PENYEBARAN POLUTAN DALAM KASUS KEBAKARAN HUTAN DAN LAHAN DI SUMATERA SELATAN TAHUN 2015
}

\author{
The Spread of Pollutants During the 2015 Forest and Land Fire \\ In South Sumatera
}

\author{
Erwin Mulyana ${ }^{1)^{*}}$ \\ 1) Balai Besar Teknologi Modifikasi Cuaca - Badan Pengkajian dan Penerapan Teknologi, Gedung \\ Ir. Mohammad Soebagio, GEOSTECH (820), Kawasan PUSPIPTEK, Serpong, Tangerang Selatan \\ *E-mail : erwin.mulyana@bppt.go.id
}

\begin{abstract}
Intisari
Kebakaran hutan dan lahan di Sumatera Selatan tahun 2015 menimbulkan bencana kabut asap yang sangat masif sehingga kualitas udara dalam beberapa hari mencapai kategori berbahaya. Dalam tulisan ini dibahas penyebaran polutan di wilayah Sumatera Selatan akibat kebakaran hutan dan lahan yang terjadi di wilayah tersebut. Data yang digunakan dalam penelitian ini adalah data hotspot dari satelit MODIS dengan tingkat kepercayaan $70 \%$, curah hujan TRMM serta curah hujan dari penakar yg ada di Sumatera Selatan, data kualitas udara (ISPU), data black carbon dari MERRA-2 Model M2T1NXAER v5.12.4. dengan resolusi $0.5^{\circ} \times 0.625^{\circ}$, serta arah dan kecepatan angin lapisan $925 \mathrm{mb}$. Analisis spasio temporal penyebaran black carbon yang dipadukan dengan arah dan kecepatan angin menggunakan perangkat lunak Grid Analysis and Display System (GrADS). Intensitas hujan dari 16 penakar hujan sejak minggu kedua bulan Agusus 2015 hingga akhir Oktober 2015 sebesar 36 mm. Selama bulan Juni-November 2015, Jumlah hotspot terbanyak terjadi pada bulan September (6.839 titik) dan Oktober (7.709 titik). Lokasi hotspot sebagian besar berada di Kabupaten OKI dengan jumlah mencapai 10.581 titik. Kualitas udara pada bulan September 2015 dominan masuk kategori tidak sehat sedangkan bulan Oktober 2015 dominan masuk kategori sangat tidak sehat - berbahaya. Angin pada lapisan $925 \mathrm{mb}$ umumnya bertiup dari arah tenggara hingga timur sehingga black carbon dari kebakaran di daerah OKI menyebar ke arah wilayah Kabupaten Musi Banyuasin serta Kabupaten Banyuasin.
\end{abstract}

Kata Kunci : Hotspot, Kabut Asap, Kualitas Udara, Black Carbon, Arah dan Kecepatan Angin.

\begin{abstract}
In 2015, Forest and Land fires inflict serious and massive smoke disaster so that air quality in several days laid in dangerous category. This paper discussed pollutant dispersed in South Sumatera due to forest and land fire in this area. Data that used in this paper were MODIS satellite hotspot data with $70 \%$ confidence level, rainfall from TRMM satellite and from ground observation at South Sumatera, Air quality data (ISPU), MERRA-2 Model M2T1NXAER v5.12.4 black carbon data, also wind direction and speed at $925 \mathrm{mb}$ height. Spatio temporal analysis of black carbon dispersion combined with wind speed and direction using Grid Analysis and Display System (GrADS) software. Rain intensity from 16 rainfall gauge since week two of August 2015 until end of October 2015 was $36 \mathrm{~mm}$. During June-November 2015, the number on highest hotspot observed was in September (6.839) and October (7.709). Hotspot location mainly in OKI district as much as 10.581. Air quality in September 2015 mainly laid in unhealthy category, meanwhile in October 2015 laid mainly stated as unhealthy to dangerous. Wind at $925 \mathrm{mb}$ height generally came from South East and East so black carbon came from fires at OKI district dispersed to Musi Banyuasin and Banyuasin district.
\end{abstract}

Keywords : Hotspot, Smog, Air Quality, Black Carbon, Wind Direction and Speed.

\section{PENDAHULUAN}

Kebakaran hutan dan lahan di kawasan gambut Pulau Sumatera dan Kalimantan kerap terjadi pada saat musim kemarau.Kebakaran hutan dan lahan dapat diakibatkan oleh aktivitas masyarakat maupun perusahaan perkebunan dalam persiapan masa tanam. Kegiatan tersebut banyak dilakukan di kawasan Asia Tenggara (Bowen et al., 2000; Chokkalingam et al., 2007; Simorangkir., 2007). Kegiatan Illegal logging dan land clearence di kawasan gambut menjadi kawasan perkebunan sawit dan hutan tanaman industri untuk kebutuhan pembuatan pulp (Miettinen \& Liew, 2010) juga berperan dalam terjadinya kebakaran hutan dan lahan. 
Pembakaran lahan tanpa pengawasan menyebabkan kebakaran yang tidak terkendali mengakibatkan bencana kabut asap yang berdampak serius di bidang kesehatan berupa gangguan pernafasan. Di bidang transportasi terutama transportasi udara mengakibatkan terjadinya penundaan hingga pembatalan jadwal pemberangkatan pesawat karena jarak pandang yang sangat rendah akibat kabut asap. Kebakaran hutan dan lahan di Indonesia berkaitan erat dengan adanya fenomena El Nino di Samudra Pasifik bagian equator (Fuller \& Murphy, 2006; Wooster et al., 2012).

Provinsi Sumatera Selatan merupakan salah satu wilayah dengan kejadian kebakaran hutan dan lahan yang cukup tinggi dan terjadi hampir setiap tahun. Kebakaran lahan dan hutan dapat dimonitor berdasarkan sebaran dan jumlah hotspot dari pantauan satelit. Puncak akumulasi kemunculan hotspot di Sumatera Selatan umumnya terjadi pada bulan AgustusSeptember, bertepatan dengan musim kemarau pada sebagian besar wilayah Indonesia.

Pada tahun 2015, kembali terjadi kebakaran hutan dan lahan di wilayah Provinsi Sumatera Selatan mengakibatkan kabut asap yang sangat mengganggu aktifitas masyarakat. Selama bulan Juni-November 2015, hotspot yang mengindikasikan terjadinya kebakaran di wilayah Sumatera Selatan mencapai 16.452 titik. Jumlah hotspot tersebut 3 kali lebih banyak dibandingkan dengan periode yang sama pada tahun 2014 yaitu sebanyak 5.085 titik.

Dalam tulisan ini dibahas mengenai jumlah dan sebaran hotspot pada bulan AgustusNovember 2015 di Provinsi Sumatra Selatan serta kualitas udara di Palembang berdasarkan nilai ISPU (Indeks Standar Pencemar Udara) maupun sebaran black carbon di atmosfer dari kebakaran hutan dan lahan di Provinsi Sumatera Selatan. Kejadian hujan serta arah dan kecepatan angin di Sumatera Selatan juga akan dibahas untuk melengkapi kajian dalam tulisan ini.

\section{METODE}

Data yang digunakan dalam tulisan ini adalah arah dan kecepatan angin pada lapisan $925 \mathrm{mb}$, data hotspot dengan tingkat kepercayaan $70 \%$ dari satelit MODIS, curah hujan serta data tingkat pencemaran udara (ISPU, Indeks Standar Pencemar Udara) di Palembang. Untuk melihat fluktuasi serta sebaran hotspot di provinsi Sumatra Selatan, arah dan kecepatan angin serta curah hujan selama musim kemarau di wilayah Provinsi Sumatera Selatan dilakukan analisis spasio temporal dengan menggunakan perangkat lunak Grid Analysis and Display System (GrADS). Analisis yang sama juga digunakan untuk melihat sebaran black carbon di wilayah Sumatra Selatan. Data black carbon dari MERRA-2 Model
M2T1NXAER v5.12.4. dengan resolusi $0.5^{\circ} \mathrm{x}$ $0.625^{\circ}$.

\section{HASIL DAN PEMBAHASAN}

\subsection{Hotspot}

Jumlah hotspot di wilayah Sumatera Selatan pada musim kemarau 2015 adalah sebagai berikut. Pada bulan Juni 2015 terdapat 66 titik dengan jumlah terbanyak terdapat di Kabupaten Muaraenim (23 titik). Jumlah hotspot semakin banyak pada bulan Juli 2015 yaitu 390 titik dan meningkat lagi menjadi 926 titik pada bulan Agustus. Pada bulan September hotspot meningkat tajam menjadi 6.839 titik, tujuh kali lebih banyak dibandingkan dengan bulan Agustus. Peningkatan jumlah hotspot masih berlangsung, pada bulan Oktober menjadi 7.709 titik. Pada bulan Nopember mulai banyak terjadi hujan sehingga jumlah hotspot berkurang drastis menjadi 603 titik. Secara keseluruhan sepanjang bulan Juni sampai November 2015, jumlah hotspot mencapai 16.452 titik dengan jumlah terbanyak berada di Kabupaten Ogan Komering Ilir (OKI) yaitu 10.581 titik (64.3\%), disusul kemudian oleh Kabupaten Musi Banyuasin dengan jumlah 2.713 titik (16.5\%) dan Kabupaten Banyuasin sebanyak 1.060 titik (4.0\%). Fluktuasi jumlah dan sebaran hotspot di Sumatra Selatan pada bulan Juni-November 2015 selengkapnya dapat dilihat pada Tabel 1.

Tabel 1. Distribusi Hotspot Bulanan di Setiap Kota/Kabupaten di Wilayah Sumatera Selatan.

\begin{tabular}{|c|c|c|c|c|c|c|c|}
\hline \multirow{2}{*}{ KABUPATEN/KOTA } & \multicolumn{6}{|c|}{2015} & \multirow{2}{*}{ TOTAL } \\
\hline & JUN & JUL & AGU & SEP & OKT & NOV & \\
\hline KOTAPALEMBANG & 0 & 1 & 0 & 1 & 1 & 0 & 3 \\
\hline KOTAPRABUMULIH & 1 & 3 & 0 & 2 & 0 & 0 & 6 \\
\hline KOTALUBUKLINGGAU & 1 & 2 & 3 & 1 & 0 & 0 & 7 \\
\hline KOTAPAGARALAM & 0 & 0 & 0 & 1 & 3 & 0 & 4 \\
\hline BANYUASIN & 5 & 28 & 137 & 485 & 382 & 23 & 1,060 \\
\hline OKI & 2 & 23 & 288 & 3,601 & 6,175 & 492 & 10,581 \\
\hline MUSI BANYUASIN & 14 & 132 & 269 & 1,844 & 422 & 32 & 2,713 \\
\hline MUARAENIM & 23 & 56 & 64 & 270 & 223 & 24 & 660 \\
\hline OGAN ILIR & 7 & 11 & 17 & 30 & 30 & 4 & 99 \\
\hline OKU & 2 & 7 & 17 & 105 & 93 & 4 & 228 \\
\hline OKU TIMUR & 7 & 7 & 12 & 40 & 44 & 0 & 110 \\
\hline OKU SELATAN & 0 & 0 & 5 & 40 & 90 & 10 & 145 \\
\hline LAHAT & 0 & 4 & 3 & 73 & 50 & 3 & 133 \\
\hline EMPAT LAWANG & 0 & 3 & 10 & 25 & 17 & 0 & 55 \\
\hline MUSIRAWAS & 4 & 32 & 101 & 321 & 179 & 11 & 648 \\
\hline TOTAL & 66 & 309 & 926 & 6,839 & 7,709 & 603 & 16,452 \\
\hline
\end{tabular}

\subsection{Curah Hujan}

Berdasarkan data hujan TRMM (Tropical Rainfall Measuring Mission) tahun 2001-2015, pola hujan di wilayah Sumatera Selatan termasuk pola equatorial yakni memiliki dua puncak musim hujan yang berlangsung pada bulan April dan bulan Desember. Sedangkan musim kemarau berlangsung pada bulan Agustus-September. Sepanjang tahun 2015, intensitas hujan bulanan 
di wilayah Sumatera Selatan sejak bulan Mei di bawah nilai rata-ratanya. Intensitas hujan bulanan paling kecil terjadi pada bulan September dan Oktober 2015. Rata-rata curah pada bulan September adalah $68 \mathrm{~mm}$, sedangkan jumlah hujan yang terjadi pada bulan September 2015 hanya $8.6 \mathrm{~mm}$, hal ini berarti hujan berkurang sebanyak $87 \%$. Hal yang sama terjadi pada bulan Oktober 2015 dengan intensitas hujan hanya $13 \mathrm{~mm}$, sedangkan rataratanya $157 \mathrm{~mm}$, ini menunjukkan bahwa pada bulan tersebut hujannya berkurang sebanyak $92 \%$.

Sementara itu berdasarkan data hujan harian dari 16 penakar hujan yang tersebar di Sumatera Selatan, sejak minggu kedua bulan Agusus 2015 hingga akhir Oktober 2015 sangat jarang terjadi hujan. Akumulasi curah hujan selama periode tersebut hanya sebesar $36 \mathrm{~mm}$. Minimnya hujan tersebut berhubungan dengan fenomena El Nino sangat kuat yang kejadiannya mirip tahun 1997/1998. El Nino merupakan fenomena yang ditimbulkan oleh interaksi lautatmosfer. El Nino merupakan fenomena memanasnya suhu permukaan laut di Samudra Pasifik di bagian tengah dan timur. Pada saat yang bersamaan terjadi perubahan pola tekanan udara yang berdampak sangat luas dengan gejala yang berbeda beda, baik bentuk dan intensitasnya. Pada saat berlangsungnya EI Nino, terjadi penguatan angin baratan di Samudra Pasifik bagian barat daerah equator mulai dari sebelah utara Irian hingga Pasifik Tengah (Trenberth \& Sea, 1987; Harrison \& Larkin, 1998; Meyers, 2007). Selama El Nino berlangsung, curah hujan di wilayah Indonesia berkurang pada bulan Juni-November (Ropelewski \& Halpert, 1987; Kane, 1997). Pada bulan September-November, curah hujan di Indonesia bagian selatan equator sangat dipengaruhi oleh El Nino (Mulyana, 2002). El Nino juga mengakibatkan awal musim hujan di Jawa lebih lambat dibandingkan dengan rataratanya (Hamada, 1995).

\subsection{Kualitas Udara}

Kebakaran hutan dan lahan di Sumatera Selatan mengakibatkan penurunan kualitas udara di Palembang dan wilayah lainnya di Sumatera Selatan. Pada Lampiran Keputusan Menteri Lingkungan Hidup, Nomor : Kep45/MENLH/10/1997, tentang Indeks Standar Pencemar Udara, tanggal 13 Oktober 1997 menyebutkan bahwa, kualitas udara kategori Baik adalah dengan nilai ISPU (indeks Standar Pencemar Udara) 0-50. Nilai ISPU 51-100 masuk kategori Sedang, ISPU 101-199 masuk kategori Tidak Sehat, ISPU 200-299 masuk kategori Sangat Tidak Sehat. dan nilai ISPU 300 atau lebih masuk kategori Berbahaya. Udara dengan kategori Baik (ISPU: 0-50) yaitu tingkat kualitas udara yang tidak memberikan efek bagi manusia atau hewan dan tidak berpengaruh pada tumbuhan bangunan ataupun nilai estetika Udara dengan kategori Sedang (ISPU: 51-100) yaitu tingkat kualitas udara yang tidak berpengaruh pada kesehatan manusia maupun hewan tetapi berpengaruh pada tumbuhan yang sensitif dan nilai estetika. Udara dengan kategori Tidak Sehat (ISPU 101-199) adalah tingkat kualitas udara yang bersifat merugikan pada manusia ataupun kelompok hewan yang sensitif atau bisa menimbulkan kerusakan pada tumbuhan ataupun nilai estetika. Sementara udara dengan kategori Sangat Tidak Sehat (ISPU: 200-299) adalah tingkat kualitas udara yang dapat merugikan kesehatan pada sejumlah segmen populasi yang terpapar. Sedangkan udara dengan kategori Berbahaya (ISPU: $\geq 300$ ) yaitu tingkat kualitas udara berbahaya yang secara umum dapat merugikan kesehatan yang serius pada populasi.

Secara keseluruhan perubahan kualitas udara di Palembang selama bulan AgustusNovember 2015 ditampilkan pada Tabel 2 berikut ini.

Tabel 2. Jumlah Hari dalam Setiap Bulan untuk Masing-Masing Kategori Kualitas Udara di Palembang.

\begin{tabular}{|c|c|c|c|c|}
\hline \multirow{2}{*}{ Kategori } & \multicolumn{5}{|c|}{ Bulan } \\
\cline { 2 - 5 } & $\begin{array}{c}\text { Agus } \\
\text { Tus }\end{array}$ & $\begin{array}{c}\text { Septem } \\
\text { ber }\end{array}$ & $\begin{array}{c}\text { Okto } \\
\text { Ber }\end{array}$ & $\begin{array}{c}\text { Novem } \\
\text { Ber }\end{array}$ \\
\hline Baik & 22 & 2 & 0 & 19 \\
\hline Sedang & 7 & 13 & 3 & 6 \\
\hline Tidak Sehat & 2 & 14 & 10 & 5 \\
\hline $\begin{array}{c}\text { Sangat Tidak } \\
\text { Sehat }\end{array}$ & 0 & 1 & 8 & 0 \\
\hline Berbahaya & 0 & 0 & 10 & 0 \\
\hline \multicolumn{5}{|c|}{ Sumber : Hasil pengolahan data ISPU di posko Karhutla }
\end{tabular}

Sumatera Selatan.

Pada bulan Agustus 2015 kondisi udara di Palembang umumnya masih dalam kategori Baik hingga Sedang, kualitas udara dengan kategori Baik berlangsung selama 22 hari $(71 \%)$, kategori Sedang selama 7 hari $(23 \%)$, dan kategori Tidak Sehat selama 2 hari (6\%). Jumlah hotspot di wilayah Sumatera Selatan pada bulan ini ada 926 titik dengan lokasi terbanyak terdapat di Kabupaten OKI (288 titik; 31.1\%), di Kabupaten Musi Banyuasin (269 titik; 29.0\%) dan di Kabupaten Banyuasin (137 titik; 14.8\%).

Bulan September 2015 terjadi lonjakan jumlah hotspot menjadi 6.839 titik yang tersebar di Kabupaten OKI 3.601 titik, Kabupaten Musi Banyuasin 1.844 titik, serta sisanya tersebar di kabupaten lainnya. Kondisi ini mengakibatkan kualitas udara semakin buruk. Kualitas udara dengan kategori Tidak Sehat mencapai 14 hari $(47 \%)$, kategori Sedang sebanyak 13 hari $(43 \%)$, Sangat Tidak Sehat 1 hari, sedangkan kondisi 
udara dengan kategori Baik hanya berlangsung selama 2 hari.

Bulan berikutnya yaitu bulan Oktober 2015 masih mengalami penambahan hotspot menjadi 7.709 titik. Pada bulan ini hotspot masih terkonsentrasi di Kabupaten OKI (6.175 titik; $80.1 \%$ ), Kabupaten Musi Banyuasin (422 titik; 5.5\%) dan Kabupaten Banyuasin (352 titik; $5.0 \%)$. Pada bulan ini kualitas udara semakin parah, yaitu dengan kategori Berbahaya selama 10 hari. Udara dengan kategori Berbahaya belum terjadi pada bulan-bulan sebelumnya. Kategori Sangat Tidak Sehat selama 8 hari dan kategori Tidak Sehat selama 10 hari serta kategori Sedang selama 3 hari. Pada bulan Oktober 2015 tidak terdapat hari dengan kualitas udara dengan kategori Baik.

Masuk bulan November 2015 mulai terjadi banyak hujan, polutan yang berada di udara tersapu air hujan sehingga kualitas udara semakin membaik. Pada bulan ini kondisi udara dengan kategori Baik mencapai 19 hari (63\%), kategori Sedang sebanyak 6 hari $(20 \%)$ dan kategori Tidak Sehat sebanyak 5 hari (17\%), tidak ada hari dengan kualitas Sangat Tidak Sehat maupun Berbahaya. Dengan mulai banyaknya terjadi hujan, jumlah hotspot juga turun tajam menjadi 603 titik dengan sebaran masih terkonsentrasi di Kabupaten OKI (492 titik; $82 \%)$.

Berdasarkan data dari Pusat Data dan Informasi Kementerian Kesehatan Republik Indonesia, kasus ISPA di Provinsi Sumatera Selatan selama periode Juli-Oktober 2015 adalah sebagai berikut: bulan Juli (22.888 kasus), Agusutus (31.899), Sptember (29.906), dan Oktober (35.711). Asap yang berasal dari kebakaran hutan (kayu dan bahan organik lainnya) mengandung campuran gas, partikel, dan bahan kimia akibat pembakaran kurang sempurna.

Komposisi asap kebakaran hutan terdiri dari gas seperti $\mathrm{CO}, \mathrm{CO}^{2}$, Nitrogen Oksida, Ozon, Sulfur dioksida dan lainnya. Partikel yang timbul akibat kebakaran hutan biasa disebut sebagai particulat matter (PM). Ukuran lebih dari 10 mikron biasanya tidak masuk paru tetapi mengiritasi mata, hidung, dan tenggorokan. Sedangkan partikel kurang dari 10 mikron dapat terinhalasi sampai ke paru. Selain itu, terdapat bahan lainnya dalam jumlah tidak terlalu banyak, seperti aldehid, polisiklik aromatik hidrokarbon, benzene, toluene, styrene, metal dan dioksin. (Masalah Kesehatan akibat kabut asap dan kebakaran hutan dan lahan tahun 2015. Pusat data dan informasi kementerian kesehaan RI, 2015. ISSN2442-7659).

Dalam jangka cepat (akut), asap kebakaran hutan akan menyebabkan iritasi selaput lendir mata, hidung, tenggorokan, sehingga menimbulkan gejala berupa mata perih dan berair, hidung berair dan rasa tidak nyaman di tenggorokan, mual, sakit kepala dan memudahkan terjadinya infeksi saluran pernafasan akut (ISPA). Dampak buruk terhadap kesehatan tersebut dapat terjadi pada setiap orang dengan masalah kesehatan pada paru dan atau jantung.

\subsection{Sebaran Black Carbon}

Black carbon dihasilkan secara alami maupun dari aktivitas manusia akibat proses pembakaran yang tidak sempurna dari bahan bakar fosil, bahan bakar nabati dan biomasa. Kebakaran hutan dan lahan juga sebagai salah satu penyumbang utama black carbon di atmosfer. Black carbon yang ada di udara hanya bertahan beberapa hari hingga beberapa minggu saja sehingga begitu sumbernya dihilangkan maka black carbon yang ada di atmosfer akan turun mengendap ke permukaan tanah.

Selama bulan September dan Oktober 2015 terjadi peningkatan black carbon di wilayah Sumatera Selatan. Kondisi ini terkait dengan adanya kebakaran hutan yang masif di wilayah tersebut yang diindikasikan dengan jumlah hotspot yang mencapai 14.548 titik selama bulan September dan Oktober 2015.

Sebaran black carbon pada bulan Agustus 2015 terkonsentrasi di wilayah Sumatera Selatan bagian tengah dan bagian utara dengan konsentrasi $2 \times 10^{-6}$ hingga $3 \times 10^{-6} \mathrm{~kg} / \mathrm{m}^{2}$. Pada umumnya angin berhembus dari tenggara dengan kecepatan 5-10 knot. Sebaran hotspot juga cukup merata di hampir seluruh wilayah Sumatera Selatan dengan jumlah keseluruhan 926 titik. Mengacu kepada nilai ISPU di Palembang dan sebaran black carbon, kualitas udara di wilayah Sumatera Selatan pada bulan Agustus 2015 umumnya masih dalam kondisi baik. Sebaran hotspot dan black carbon serta arah dan kecepatan angin pada bulan Agustus 2015 bisa dilihat pada Gambar 1.

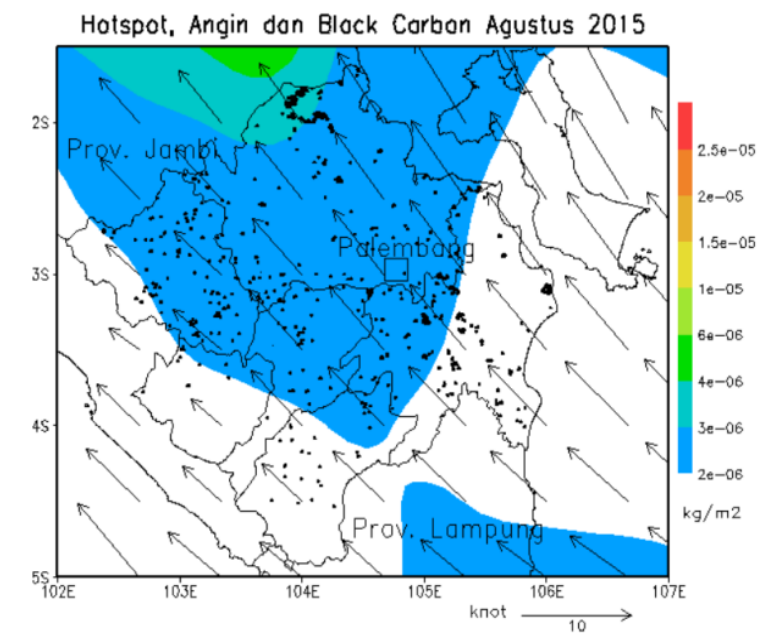

Gambar 1. Sebaran hotspot, black carbon serta arah dan kecepatan angin pada bulan Agustus 2015.

Pada bulan berikutnya, sebaran black carbon semakin luas dan semakin pekat seiring 
dengan terjadinya lonjakan jumlah hotspot di wilayah Sumatera Selatan yaitu pada bulan September 2015 menjadi 6.839 titik.

Sumber black carbon dari kebakaran hutan dan lahan di Kabupaten OKI menyebar terbawa angin ke arah barat laut menyelimuti atmosfer wilayah Kabupaten Banyuasin dan Kabupaten Musi Banyuasin. Kedua daerah tersebut merupakan wilayah yang paling banyak terpapar black carbon dengan konsentarsi $1 \times 10^{-5}$ hingga $2 \times 10^{-5} \mathrm{~kg} / \mathrm{m}^{2}$. Sementara konsentrasi black carbon di bagian selatannya relatif lebih rendah dibandingkan dengan ke dua wilayah kabupaten tersebut.

Arah angin masih dominan dari tenggara dengan kecepatan masih berkisar 5 - 10 knot. Jumlah hotspot pada bulan September di Kabupaten OKI ada 3.601 titik, Kabupaten Musi Banyuasin 1.844 titik dan di Kabupaten Banyuasin 485 titik. Sebaran hotspot dan black carbon serta arah dan kecepatan angin pada bulan September 2015 bisa dilihat pada Gambar 2.

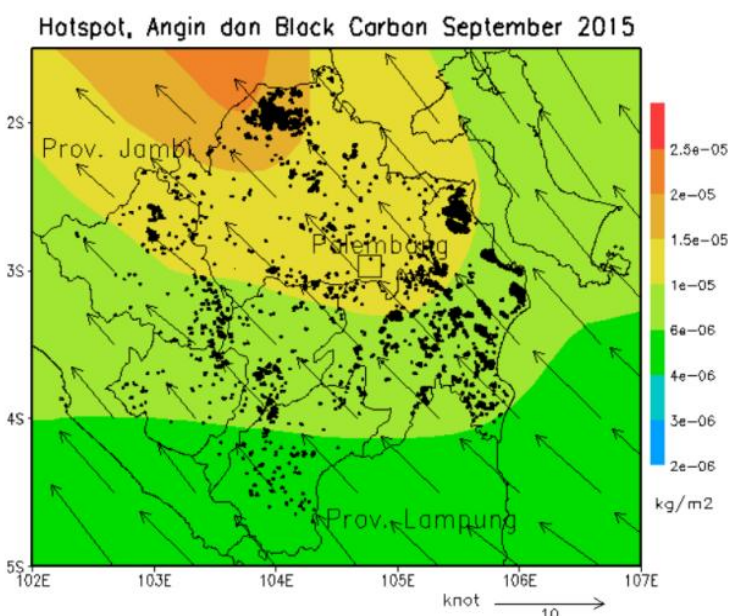

Gambar 2. Sama seperti Gambar 1 tetapi untuk bulan September 2015.

Konsentrasi black carbon terus mengalami peningkatan di seluruh wilayah Sumatera Selatan. Konsentrasi black carbon yang paling tinggi terdapat di Kabupaten Banyuasin serta di Kabupaten Musi Banyuasin. Pada bulan September 2015 mencapai $1 \times 10^{-5}-2 \times 10^{-5} \mathrm{~kg} / \mathrm{m}^{2}$ dan pada bulan Oktober 2015 meningkat tajam menjadi $2 \times 10^{-5}-3 \times 10^{-5} \mathrm{~kg} / \mathrm{m}^{2}$. Kondisi ini akibat semakin banyaknya kebakaran hutan dan lahan di Kabupaten OKI dengan jumlah hotspot mencapai 6.175 titik. Jumlah keseluruhan hotspot di wilayah Sumatra Selatan pada bulan Oktober 2015 mencapai 7.709 titik. Pada bulan Oktober, arah angin cenderung menuju barat dengan kecepatan 5-10 knot. Perubahan arah angin ini menyebabkan sebaran black carbon cenderung melebar ke arah barat.

Sebaran hotspot dan black carbon serta arah dan kecepatan angin pada bulan Oktober 2015 diperlihatkan pada Gambar 3.

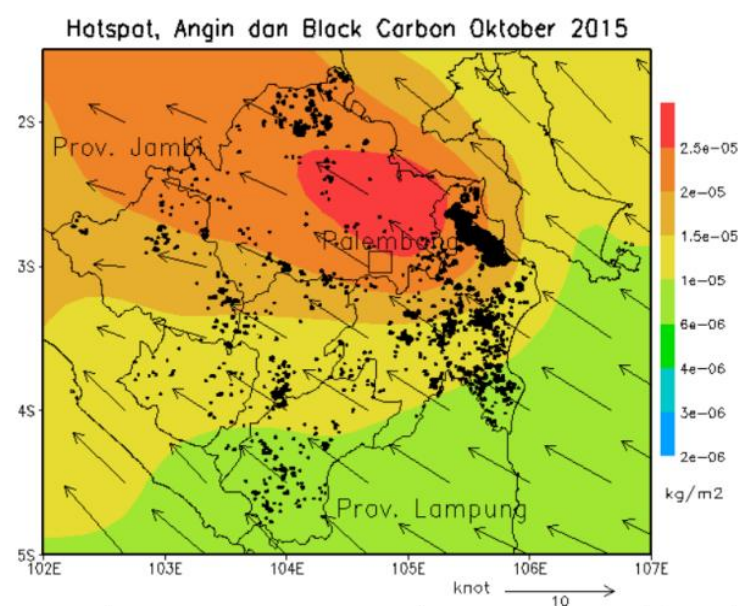

Gambar 3. Sama seperti Gambar 1 tetapi untuk bulan Oktober 2015.

Di Kabupaten Musi Banyuasin terjadi peningkatan tajam konsentrasi black carbon, padahal jumlah hotspotnya mengalami penurunan dari 1.844 titik pada bulan September menjadi 422 titik pada bulan Oktober. Hal ini bisa terjadi karena black carbon yang berasal dari kebakaran hutan dan lahan di Kabupaten OKI terbawa angin dan sampai di Kabupaten Musi Banyuasin. Faktor lain karena adanya pelambatan kecepatan angin dibandingkan dengan kecepatan angin pada bulan sebelumnya, sehingga semakin memperbesar penumpukan black carbon di Kabupaten Musi Banyuasin.

Pada bulan November 2015 mulai banyak turun hujan di wilayah Sumatera Selatan sehingga hotspot juga berkurang drastis menjadi 603 titik. Akibat berkurangnya jumlah kebakaran hutan dan lahan sebagai sumber black carbon maka konsentarsi black carbon juga ikut berkurang menjadi $2 \times 10^{-6}-6 \times 10^{-6} \mathrm{~kg} / \mathrm{m}^{2}$. Secara umum pada bulan November 2015 kualitas udara sudah membaik. Angin berubah menjadi angin timuran dengan kecepatan 1-5 knot. Sebaran hotspot dan black carbon serta arah dan kecepatan angin pada bulan November 2015 diperlihatkan pada Gambar 4.

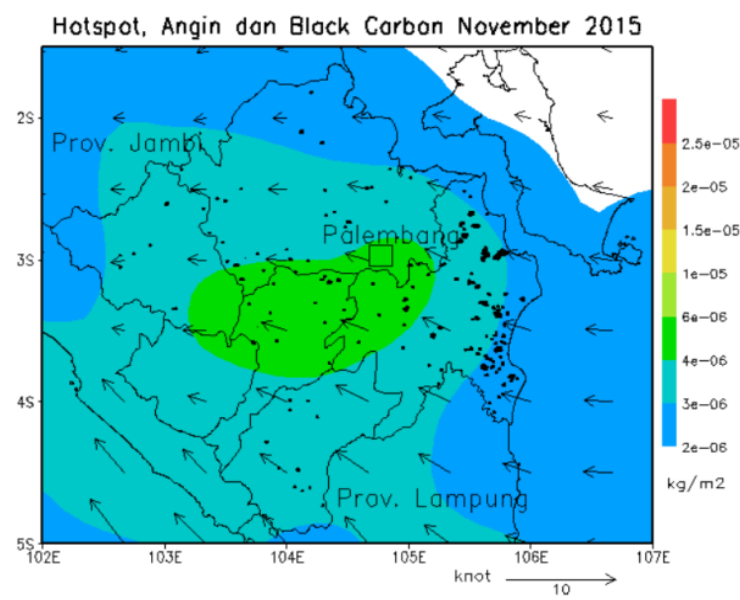

Gambar 4. Sama seperti Gambar 1 tetapi untuk bulan November 2015. 


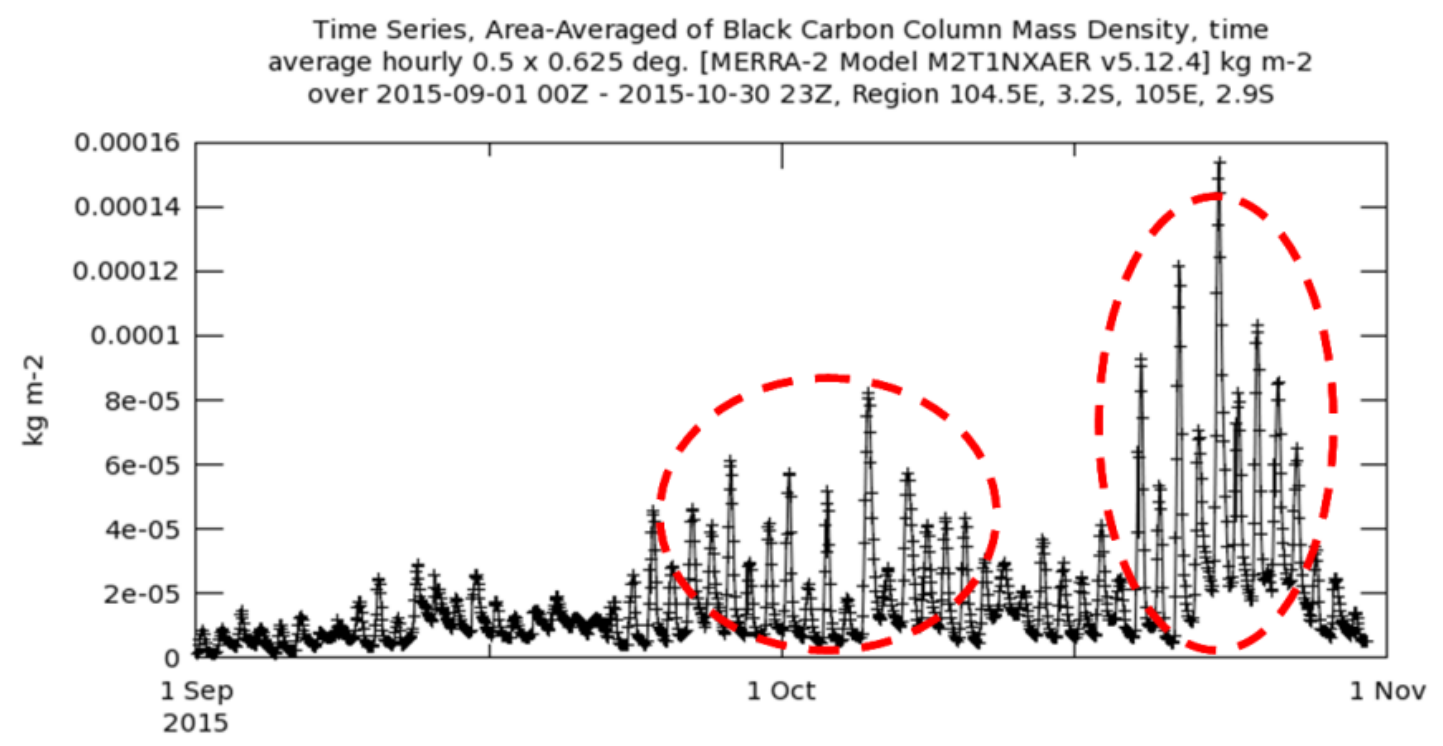

Gambar 5. Variasi jam-jaman konsentrasi Black Carbon di wilayah Sumatera Selatan pada bulan September-Oktober 2015.

Variasi jam-jaman black carbon di Sumatera Selatan yang diwakili oleh area $104.5^{\circ}$ - $105^{\circ}$ BT ; $2.9^{\circ}-3.2^{\circ}$ LS menunjukkan bahwa konsentrasi tertinggi black carbon terjadi pada tanggal 23 Oktober 2015 jam 16 WIB dengan konsentrasi mencapai $1.5 \times 10^{-4} \mathrm{~kg} / \mathrm{m}^{2}$. Secara umum konsentrasi black carbon di wilayah Sumatera Selatan berlangsung pada akhir September - awal Oktober 2015 serta pada pertengahan - akhir Oktober 2015 seperti ditunjukkan dengan tanda lingkaran pada Gambar 5.

\section{KESIMPULAN}

Berdasarkan hasil kajian penyebaran polutan kebakaran hutan dan lahan di Sumatera Selatan dapat diambil kesimpulan sebagai berikut:

1. Kebakaran hutan dan lahan paling banyak terjadi pada Oktober 2015 dengan jumlah hotspot 7.709 titik dan bulan September 6.839 titik. Sementara wilayah yang paling banyak mengalami kebakaran adalah di Kabupaten OKI dengan hotspot mencapai 9.776 titik dan Kabupaten Musi Banyuasin 2.266 titik.

2. Bulan September dan Oktober 2015 di wilayah Sumatera Selatan sangat kering. Intensitas hujan pada bulan September 2015 hanya $8.6 \mathrm{~mm}$ (historis $68 \mathrm{~mm}$ ), sedangkan pada bulan Oktober 2015 sebesar $13 \mathrm{~mm}$ (historis $157 \mathrm{~mm}$ ). Kondisi kering ini berhubungan dengan kejadian El Nino sangat kuat.

3. Kualitas udara di Palembang yang paling buruk terjadi pada bulan Oktober 2015 dengan kategori Berbahaya mencapai 10 hari, sangat Tidak Sehat 8 hari dan Tidak Sehat 10 hari.

4. Daerah yang paling terpapar black carbon adalah kabupaten Banyuasin dan Kabupaten
Musi Banyuasin. Black carbon tersebut berasal dari kebakaran di Kabupaten OKI, bergerak terbawa angin ke arah barat laut hingga akhirnya terkumpul di atmosfer wilayah Kabupaten Musi Banyuasin dan Kabupaten Banyuasin.

\section{DAFTAR PUSTAKA}

Bowen, M.R., Bompard, J.M., Anderson, I.P., Guizol, P., Guyon, A. (2000). Anthropogenic Fires in Indonesia: A View from Sumatra. Forest Fires Prevention and Control Project Reports. Nova Science, New York.

Chokkalingam, U., Suyanto, Permana, R.P., Kurniawan, I., Mannes, J., Darmawan, A., Khususyiah, N., Susanto, R.H. (2007). Community Fire Use, Resource Change, and Livelihood Impacts: The Downward Spiral in The Wetlands of Southern Sumatra. Mitigation and Adaptation Strategies of Global Change, 12(1), 75100. doi: 10.1007/s11027-006-9038-5

Fuller, D.O., Murphy, K. (2006). The ENSO-Fire Dynamic in Insular Southeast Asia. Climatic Change, 74(4), 435-455. doi: 10.1007/s10584-006-0432-5

Hamada, J.I. (1995). Climatological Study on Rainfall Variationin in Indonesia. Master's Thesis, Geophysical Institute, Kyoto University.

Harrison, D.E., Larkin, N.K. (1998). El NinoSouthern Oscillation Sea Surface Temperature and Wind Anomalies, 19461993. Review of Geophysics, 36(3), 353399. doi: 10.1029/98RG00715

Kane, R.P. (1997). Relationship of El NinoSouthern Oscillation and Pacific Sea Surface Temperature with Rainfall in Various Regions of the Globe. Monthly 
Weather Review, 125(8), 1792-1800. doi:10.1175/1520-

0493(1997)125<1792:ROENOS>2.0.CO;2

Meyers, G., Mcintosh, P., Pigot, L., Pook, M. (2007). The Years of El Nino, La Nina, and Interactions with the Tropical Indian Ocean. Journal of Climate, 20(13), 28722880. doi: $10.1175 / \mathrm{JCL} 14152.1$

Miettinen, J., Liew, S.C. (2010). Degradation and Development of Peatlands in Peninsular Malaysia and in the Islands of Sumatra and Borneo Since 1990. Land Degradation \& Development, 21(3), 285-296. doi: $10.1002 / \mathrm{ldr} .976$

Mulyana, E. (2002). Hubungan antara ENSO dengan Curah Hujan di Indonesia. Jurnal Sains \& Teknologi Modifikasi Cuaca, 3(1), $1-4$.

Ropelewski, C.F., Halpert, M.S. (1987). Global and Regional Scale Precipitation Patterns
Associated with the El Nino-Southern Oscillation. Monthly Weather Review, 115(8), 1606-1626. doi: 10.1175/15200493(1987)115<1606:GARSPP>2.0.CO;2

Simorangkir, D. (2007). Fire Use: Is It Really the Cheaper Land Preparation Method for Large-Scale Plantations? Mitigation and Adaptation Strategies of Global Change, 12(1), 147-164. doi: 10.1007/s11027-0069049-2

Trenberth, K.E., Shea, D.J. (1987). On the Evolution of the Southern Oscillation. Monthly Weather Review, 115(12), 30783096 . doi: 10.1175/15200493(1987)115<3078:OTEOTS>2.0.CO;2

Wooster, M.J., Perry, G.L.W., Zoumas, A. (2012). Fire, Drought and El Niño Relationship on Borneo (Southeast Asia) in the Pre-MODIS Era (1980-2000). Biogeosciences, 9(1), 317-340. doi: 10.5194/bg-9-317-2012 